\title{
Physical And Geographical Description Of The Surkhandarya Basin And The Current State Of The Study Of Paleogene Deposits
}

\author{
Qurbonova Mohigul Mamasaliyevna \\ Doctoral Student Of The Department Of Geology, National University Of Uzbekistan Named \\ After Mirzo Ulugbek, Uzbekistan
}

Journal Website:

http://usajournalshub.c

om/index,php/tajssei

Copyright: Original

content from this work

may be used under the

terms of the creative

commons attributes

4.0 licence.

\section{ABSTRACT}

This article describes the physical and geographical description of the Surkhandarya basin and the degree of study of Paleogene deposits.

\section{KEYWORDS}

Neogen, deposits, depression, stratigraphy, Paleocene, fauna, anticline, flammable shale.

\section{INTRODUCTION}

The area under study is bounded by the southwestern coordinates of the Gissar mountain range, which are $38^{\circ} 05-38^{\circ} 1730$ North latitude b $7^{\circ} 00-67^{\circ} 2615$ east.

The Republic of Uzbekistan is part of the Surkhandarya region. This described region includes the periphery of the southwestern Boysun mountainous region and the one-sided depression of the northeast. Orographically, it is divided into 2 zones, which alternate with each other from time to time. The northeastern part reflects the mountainous regions with an absolute height of $1200 \mathrm{~m}$ to $2450 \mathrm{~m}$.
A general decrease in absolute heights is observed from northeast to southwest. The relative elevation is around $100-200 \mathrm{~m}$. In the south of this zone monoclinic ridges are developed (g. Oksog-ota, Karakutan, Galchalyk, Shirgiyos, Gurgurak, Boboxazon). They have a meat row structure. The resulting slope is composed of distinctly distinct Paleocene limestone, as well as sandstone and limestone from the Bukhara horizon. The rows lie parallel to each other and are generalized in relief. The mountainous region is replaced by steppe hills in the direction of depression. The boundary between them runs along a line 
extending from the southwest to the northeast of the area described by the limestone rows in which the Paleocene limestones are placed. The hills are composed of Neogene and Quaternary deposits. They reflect the elevation signs of the foothills. It was not higher than $1200 \mathrm{~m}$. Proluvial plain of Sherabad region. The main water source is located in the area of Sherabad district. Its width and distance are not constant and increase periodically along the flow. The average width of the river is $10-15 \mathrm{~m}$, the depth is $0.5 \mathrm{~m}$ to $1.5 \mathrm{~m}$. In winter and autumn the water of the river decreases to a minimum, and in spring and early summer it increases several times. The river is saturated by atmospheric sediments. The river is mainly saturated with snow and rain. The flow in the river is not constant. The climate of the described region is continental. According to the Boysun meteorological station, the average number of annual atmospheric sediments is $390-423 \mathrm{~mm}$, Their distribution is almost uneven. During the summer, the total annual precipitation does not exceed 5-10 percent. The main part of the precipitation falls in the spring, winter, autumn months. Between June, July and August of summer, the average temperature of the moon ranges from $35^{\circ}-40^{\circ}$ in the plains, and $20-25^{\circ}$ in the MOUNTAINOUS areas. The hottest month from there is June in the year. The air temperature here is sometimes higher than 45 '.In winter, December, January, February are very cold, the air temperature sometimes drops to - $20-25^{\circ} \mathrm{C}$. The average temperature of the moon is $1-4^{\circ} \mathrm{C}$ in winter. The average annual temperature is $13^{\circ} \mathrm{C}$.

The wind blows more in the southwest and west. Their average speed is $2-3 \mathrm{~m} / \mathrm{s}$, but the wind, called Afghanshamol, blows very often from the south, dry wind, dust, dust. It takes place once a week, 1-2 times in summer and 1-2 times a month in winter. Climate has an impact on the plant world. This is the case in more mountainous areas. Because those lands are wet.

In these humid places grasses, plants are very developed. They will survive almost until the end of June, but will dry up on the hillsides by the end of May. In the northern part of the area, where the absolute heights are higher than $1500 \mathrm{~m}$, spruce grows.

The most densely populated point is the Boysun district center in the Boysun area we are describing as a district. There are human settlements Aula, Chinabad, Pulkhanim, Dashtigaz, Kofirun, Rabot, which are located around the city of Boysun and are connected by dirt and asphalt roads. An asphalt road ran over the square from west to east.

The nearest railway is the Shurchi Railway, located $60 \mathrm{~km}$ south of the Aulattoda district (south). The main part of the population is Uzbek and Tajik people engaged in animal husbandry, agriculture and poultry. Production is very slow in the region. Boysun has a silk weaving factory and brick factories.

The Paleogene deposits of Surkhandarya are the most promising for the exploration of various mineral deposits. Therefore, research, thematic and research work has been carried out in this area for many years. Due to medium and large-scale geological mapping, a large amount of material on the geological structure, stratigraphy, material composition of deposits and minerals was collected. Geological mapping works were carried out by $\begin{array}{lrr}\text { Ya.B.Aysanov, } & \text { G.V.Brailov, } & \text { A.K.Bukharin, } \\ \text { V.I.Zonov, } & \text { V.S.Korsakov, } & \text { Kutepov, }\end{array}$ 
N.I.Poznyakov, M.M. Conducted by Purkin, K.K.Pyatkov, A.K.Pyatkov, H.Sarbaev, A.V.Tolokonnikov, R.R.Usmanov, N.L.Chvanov, V.V.Shkarupa and others. AA Abdusamatov, NV Averburg, VG Balakhmatova, IG Belenkaya, KV Bobkov, OS Vyalov, RF Gekker on stratigraphy, fauna and paleoecology in different years , B.P.Jijchenko, L.P.Kaxanova, I.A.Korobkova, A.R.Kushokov, R.X.Lipman, R.K.Makarova, N.E.Minakova, S.X.Mirkamalova, L .V.Mironova, A.M.Mosyakova, A.I.Osipova, O.M.Rasulov, E.F.Tsatsir and others.

General issues of geology, lithology and facies conditions of formation of Surkhandarya paleogenic deposits extensively covered in his work. Extensive work has been done on minerals, their conditions of formation and application in practice.

The conditions of formation and industrial significance of combustible shales were studied by AG Luzanovsky, RN Nishankhodjaev, AS Fedorenko and others. The south-western parts of the Gissar mountain range are geologically very interesting and have attracted the attention of many searchers since ancient times.

N.P.Turaev (1931), N.P.Lupov (1938-1959), O.S. Vyalov (1939), S.N. Simakov (1938-1946), N. E.. Minakova (1948), K.A. Sotiriadi, E.A. Zhukova, V.D. Ilin (1958 - 1962) and others. As a result of the work of the above-mentioned authors, extensive information was obtained on the tectonics, stratigraphy, paleogeography of the Meso-Cenozoic deposits in the south-western parts of the Gissar mountain range and the adjacent territory. 1938y. Simakov I: Geologically surveyed the stratigraphy of the Boysun basin at a scale of 2,500. These investigations revealed 2 previously unknown anticline structures. This structure is covered with Neogene deposits. 1942 y. M.I. Sostnina conducted geological work with Eocene combustible shales in the Boysun deposits. As a result, flammable shale in layers $\mathrm{V}, \mathrm{S} 1$, S2 was excavated for 15 miles. tons of reserves were identified.

In 1940-1943, BV Yaskovich and others conducted prospecting and exploration work in the Boysun coal deposits. Jurassic coal reserves were estimated at 26.5 million tons. In 1948-1949, A.K. Preobrazhensky, GK Lyashenko conducted a geological survey at a scale of 1: 100,000. On their side were written all the tectonic elements of the region. (Ketmon, Chopdi, Surkhantovu and Sherobot, Sariqamish anticlines.)

1951y. VVYaskovich, G.Yu.Alferov conducted search work at the site of ore formation of galena named after Aulat. As a result of these studies, polymetallic mineralization was found in sandstones belonging to the Apt stratum. In the same tier, Chikrizov G.S. and K.V.Ryskina compiled a geological map at a scale of 1 : 200,000 . All the materials belonging to this period belonging to this period are summarized in it. All major tectonic elements were written by them.

Berdiboy anticline - the south-western part of the Surkhan mountain range is characterized by an unnamed fold.

1952y. T.Ya. Bronstein and A.N. Naumov on behalf of the Termezneft Trust conducted a 1: 100,000 geological survey around the Boysun region. The purpose was to drill for oil and gas.

The authors recommended that the Berdiboy anticline be geologically surveyed here because it is rich in oil and gas (in the future). 
1953y. A.D. Jmulevich conducted prospecting work in ore ore mining in Aulat. As a result of these works, mineralization was observed up to $3 \mathrm{~km}$.

From 1959 to 1960, Al Popov, G.A. Rusakov and others conducted surface exploration work in the Boysun GSP area. The resulting emonatsionalnaya syomka was associated with Paleogene combustible shales. Darband I, Darband P, Aulat, and other anomalies were identified. The activity of flammable shales is $47 \mathrm{mkr}$. $150 \mathrm{mkr}$ per hour. up to an hour.

In each anomaly, they are observed from $50 \mathrm{~m}$ to $200 \mathrm{~m}$ along a flat surface. $1960 \mathrm{y}$. I.Ishankulov and M.A. Karasev conducted a metallometric survey in the northern part of the square. As a result, in the village of Aylat in the region were restored areas with a content of $0.005 \%$ to $0.04 \%$, lead and copper from $0.005 \%$ to $0.04 \%$. Another 0.02-0.03 percent zinc was also seen. In 1961-1962, R.I. Abramson, M.N. Astafeva conducted deep seismic drilling crossing the Boysun GSP area. As a result, the deep construction of part of the Boysun basin, the relatively sloping part of the foundation, lies at a depth of $5200 \mathrm{~m}$. The Upper Jurassic deposits are $4350 \mathrm{~m}$.

1962-1967 Yu.S. Lor Khodkevich conducted searches at the Boysun district's combustible shale complexes and the coal mine of the same name. As a result, the thickness of the combustible shale was observed from $0.36 \mathrm{~m}$ to $0.7 \mathrm{~m}$ to $50.7 \mathrm{~m}$. Coal and flammable shales have been identified.

In 1965-1966, FM Fattakhov conducted a 1: 50,000 scale state geological survey of the area. The result of this work falls on the Ketmen-Chopi and Darband anticline. $1965 \mathrm{y}$.
V. Ilyashenko, A. Phosphorites were explored around the Baratov Boysun district. Phosphorites have been found among Paleogene deposits.

1968 y. NN Nesterovich and SH Siddikova conducted a seismic profile on the Bayangar and Gadjak structures.

1969 y. Around the Bayangar, Gadjak and Jonbosh structures, Uzbekneft has drilled deep wells in search of oil and gas.

In 1968-1971, Ya.N. He was also successful as a result of this work.

1973 y. NE Minakova Drilling was carried out in the Surkhandarya basin to separate the Cretaceous and Paleogene boundaries, but the issue remained open.

In 1984, a single regional MOGT profile was developed in the southern half of the Surkhandarya megasyncline. For the first time, incisions were made in the Upper Jurassic deposits for 4.3-4.6 s.

In 1990, the geological structure of the Gadjak anticline of saline Jurassic rocks was described in detail and 23 search sites were identified, some of which (Kyzylkiya). , Cane, etc.) confirmed by seismic OGT.

In 1994 and 2000, the Central Thematic Cosmogeological Party (Glux AK) conducted a regional analysis of the linear network throughout Uzbekistan. As a result, linear and arc elements of the interpretation were identified. They are used in the production activities of geological prospecting organizations to map buried anticlines (ring structures) and to identify cracks in the ground. 
2000-2001 y. Abdusamatov A.A. Bogomolova A.M. Filatova R.V. Fieldwork was carried out in the south-western foothills of the Gissar Mountains, and as a result, complexes of living things were studied, foraminiferal, nanoplankton soft-lying, stratified zones were observed or newly identified in neighboring areas.

2005 y. Yu.G.Pedder provided an opportunity to study the level of exploration of Paleogene deposits within the structural-tectonic zones of the Surkhandarya megacline, to assess the oil prospects of individual regions and zones, to identify primary sites for oil exploration and to develop methodological methods.

In order to expand the scope of geological prospecting in the territory of the Republic of Uzbekistan after independence, the Cabinet of Ministers of May 3, 2000 No. 176-29 "On measures to strengthen oil and gas exploration" and December 29, 2000 No. 515 Resolutions "On additional measures to strengthen oil and gas exploration" were adopted, on the basis of which the main forecast indicators of geological exploration for the period up to 2005 were identified. As a logical continuation of the above decisions for future targeted geological prospecting in the territory of the Republic of Uzbekistan, the Cabinet of Ministers of August 13, 2004 No. 394-64 "On increasing natural gas exports and modernization of gas transmission systems for 2004-2020, A new resolution "On measures to accelerate geological prospecting" was adopted.

As a logical continuation of the above decisions for future targeted geological prospecting in the territory of the Republic of Uzbekistan, the Cabinet of Ministers of August 13, 2004 No. 394-64 "On increasing natural gas exports and modernization of gas transmission systems for 2004-2020, A new resolution "On measures to accelerate geological prospecting" was adopted.

In order to provide mechanisms for the implementation and implementation of this decision, this "Strategic Program of oil and gas exploration in the territory of the Republic of Uzbekistan for the period 2005-2020" was developed. This program consists of 6 volumes; Volume I Ustyurt region (1 book program text, 2 books - graphic drawings); Volume II - Bukhara-Khiva region (1 book program text, 2 books - graphic drawings); Volume III - Gissar region (1 book - program text, 2 books - graphic drawings); Volume IV Surkhandarya region (1 book - program text, 2 books - graphic drawings); Volume V - Fergana region ( 1 book - program text, 2 books graphic drawings); Volume VI - General information on the territory of Uzbekistan (1 book - the text of the program, 2 books graphic drawings).

Volume IV, which covers the Surkhandarya region, contains geodynamic and paleogeological conditions, geological and geophysical data revealing the deep geological structure, the volume of geological prospecting, financing, taking into account the estimated oil and gas resources of the region, hydrocarbon potential and material and technical resources. as well as the projected growth of hydrocarbon reserves with calculated economic indicators and a number of recommendations on how to increase the attraction of foreign investment.

A very large team of specialists from Uzgeoburgineftegazkazibchikarish JSC, Uzbekgeofizika OJSC and IGIRNIGM OJSC took part in the preparation of this program: 
A.V. Kirshin UzR.FA academician .T.L. Bobojonov F.G. Dolgopolov X.N. Musaev B.U. Nishonov A.X. Nugmanov M.V. Parpiev Yu.G. Pedder A.A. Polikarpov S.R. Ramazanov M.M. Sydikov G.S.Solopov A.I. Gadoev, N.I. Ivina, S.S. Qochqorova, G. X. Kim and A.I. Khodjimetov and the director of JSC "IGIRNIGM", g.-m. f.d, Professor A.A. Edited under the general scientific guidance of Abidov. During the period from 2005 to 2020, the following increase in hydrocarbon reserves in the Surkhandarya region is projected; natural gas 198.3 billion m3 (19.5\% of the total share in the country); liquid hydrocarbons (oil + condensate) $9.6 \mathrm{mln}$. t. ( $14.2 \%$ of the total share in the country).

For the last half century, the main object of exploration and prospecting for oil and gas fields in Southern Uzbekistan has been the formation of Paleogene carbonate. In this case, the rifogenic structures, which are identified by many experts as the object of study, are becoming increasingly important.

Carbonate formation deposits have been studied by researchers in various fields (facies, lithological, petrographic, paleontological, etc.) and to date, a number of indicators that reveal the characteristics of this formation are controversial. This applies to ideas about the laws and nature of the location of rifogenic structures, the classification, comparison, and stratigraphic size of such arrays. Although carbonate formation deposits contain a wide range of different organisms: mollusks, foraminepheres, ostrocodes, algae, and so on. although it is known that nanoplankton remains have not been well studied to this day.

Nannoplankton remains have been identified worldwide by KA Khodjakhmedov
(Turkmenistan), NG Muzilyov (Moscow), A. P.Sautkin (Russia), Ovechkina M.N. (Russia) and only AR Kushakov from the Republic of Uzbekistan studied Fergana and Kyzylkum regions of Uzbekistan.

\section{REFERENCES}

1. Biostratigraphic scheme of Paleogene deposits of the southwestern spurs of the Gissar ridge and Central Kyzylkum (Kuldzhuktau), 1981 (Publishing house science, "Science" Moscow 1974.

2. Vyalov O.S. Paleogene stratigraphy of Central Asia Ann.Intt Geol.Publ.Hung / T. LIV. 11, Budapest. 1971

3. Kushakov A.R. Calcareous nannoplankton and stratigraphy of the Paleogene of Uzbekistan abstract 1999.

4. Kushakov A.R. Nannoplankton stratigraphy of the Eocene deposits of Ustyurt. Uzbek Geological Journal, No. 1 Art. 11-14 2004

5. Kushakov A.R Correlation of Eocene deposits of Uzbekistan on complexes of calcareous nannofossils UzMu Khabarlari 2007 №1.

6. Kushakov A.R., Ibragimov R.N. Biotic characteristics of the Paleogene of Eastern Uzbekistan UzMu Khabarlari 2007 №1Muzylev N.G. Significance of nannoplankton for the zonal division of Paleogene deposits in the south of the USSR. In the book: "Questions of micropaleontology". Issue 19. M., Science, 1977

7. Minakova N.E., Sotiriadi K.A., Egamberdiev M., Nasretdinov Z.Z., Khikmatullaev B.S., Talipov S. Lithology, stratigraphy, geochemistry and oil and gas potential of the Paleogene deposits 
of the Surkhandarya depression. Ed.

"Fan", UzSSR, Tashkent, 1974. 